\title{
Functional inactivation of the IGF-I receptor delays differentiation of skeletal muscle cells
}

\author{
Z-Q Cheng ${ }^{1}$, S Adi ${ }^{1}, \mathrm{~N}-\mathrm{Y} \mathrm{Wu}^{1}{ }^{1}, \mathrm{D}$ Hsiao ${ }^{1}, \mathrm{E}$ J Woo ${ }^{1}$, \\ E H Filvaroff ${ }^{2}$, T A Gustafson ${ }^{3}$ and S M Rosenthal ${ }^{1}$ \\ ${ }^{1}$ Department of Pediatrics, University of California, San Francisco, California 94143, USA \\ ${ }^{2}$ Department of Growth and Development, University of California, San Francisco, California 94143, USA \\ ${ }^{3}$ Section of Signal Transduction, Metabolex, Inc., Hayward, California 94545, USA \\ (E H Filvaroff is now at Department of Endocrinology, Genentech, Inc., South San Francisco, California 94080, USA) \\ (Requests for offprints should be addressed to S M Rosenthal, Division of Pediatric Endocrinology, University of California, San Francisco, \\ California 94143-0434, USA; Email: smr@itsa.ucsf.edu)
}

\begin{abstract}
Skeletal myoblasts are inherently programmed to leave the cell cycle and begin the differentiation process following removal of exogenous growth factors. Serum withdrawal results in a marked induction of IGF production which is essential for skeletal muscle differentiation in vitro. However, the potential role of the tyrosine kinase IGF-I receptor (thought to be the principal mediator of both IGF-I and II signaling in skeletal muscle) in the decision of myoblasts to begin differentiation following serum withdrawal is unknown. To explore the role of the IGF-I receptor in this decision by skeletal myoblasts, we functionally inactivated endogenous IGF-I receptors in mouse C2C12 cells using a dominant negative, kinase-inactive IGF-I receptor in which the ATP-binding site lysine (K) at residue 1003 has been mutated to alanine (A). Cell lines with the greatest degree of mutant IGF-I receptor expression $(A / K$ cells) demonstrated functional inactivation of endogenous IGF-I receptors as determined by their impaired ability to phosphorylate the principal substrate of the IGF-I receptor, IRS-1, in response to treatment with
\end{abstract}

IGF-I. In addition, the proliferative response of myoblasts to IGF-I was completely abolished in A/K cells. Following withdrawal of exogenous growth factors, $\mathrm{A} / \mathrm{K}$ cells demonstrated a marked delay in the induction of the gene expression of myogenin, a skeletal muscle-specific transcription factor essential for differentiation, and a subsequent delay in the induction of muscle creatine kinase activity. Delayed differentiation in $\mathrm{A} / \mathrm{K}$ cells was associated with prolonged phosphorylation of the cell cycle regulatory retinoblastoma $(\mathrm{Rb})$ protein; it is the un- (or hypo-) phosphorylated form of $\mathrm{Rb}$ which is known to promote differentiation in skeletal myoblasts. Thus, the IGF-I receptor regulates the timing of myoblast differentiation induced by serum withdrawal. The delayed differentiation of skeletal myoblasts with functionally inactive IGF-I receptors may result, at least in part, from delayed induction of myogenin gene expression and prolonged phosphorylation of the $\mathrm{Rb}$ protein.

Journal of Endocrinology (2000) 167, 175-182

\section{Introduction}

Skeletal myoblasts are inherently programmed to leave the cell cycle and begin the differentiation process following removal of exogenous growth factors (Molkentin \& Olson 1996). Serum withdrawal results in a marked induction of insulin-like growth factor (IGF) peptide production several days before attainment of the mature muscle phenotype (Tollefsen et al. 1989a, b. Florini et al. 1991, Rosenthal et al. 1991, Rosen et al. 1993), and IGF antisense oligodeoxynucleotides or cRNAs inhibit the differentiation process (Florini et al. 1991, Montarras et al. 1993).

While autocrine/paracrine production of IGF peptides plays a critical role in muscle differentiation, the potential role of the IGF-I receptor in the decision of skeletal myoblasts to begin differentiation following serum withdrawal is unknown. The tyrosine kinase IGF-I receptor is thought to be the principal mediator of both IGF-I and IGF-II signaling in skeletal muscle and in a wide variety of tissues (Ewton et al. 1987, LeRoith et al. 1995). IGF-I receptors are abundant in murine skeletal myoblasts (Beguinot et al. 1985, Tollefsen et al. 1989a, Rosenthal et al. 1991), including C2C12 cells (Palmer et al. 1997), during initiation of the differentiation process which occurs following serum withdrawal.

To explore the role of the IGF-I receptor in the ability of skeletal myoblasts to begin differentiation following serum withdrawal, we functionally inactivated the IGF-I receptor by a dominant negative strategy using a 
kinase-inactive IGF-I receptor. The dominant negative strategy for functional inactivation of endogenous IGF-I receptors is based on knowledge that the IGF-I receptor is a heterotetrameric complex resulting from dimerization of two proreceptor monomers, each of which is processed into $\alpha$ and $\beta$ subunits (LeRoith et al. 1995). Ligand binding is thought to induce a conformational change in the IGF-I receptor which ultimately leads to its activation (LeRoith et al. 1995). Activation of the IGF-I receptor, itself a tyrosine kinase, results principally from intramolecular trans-autophosphorylation of one $\beta$-subunit by the other $\beta$-subunit within the receptor complex (Frattali \& Pessin 1993). Previous studies have shown that overexpressed human IGF-I receptors form hybrids with endogenous rodent IGF-I receptor halves (Prager et al. 1992, Kato et al. 1993, Li et al. 1994, Prager et al. 1994, Webster et al. 1994, Burgaud et al. 1995, Kulik et al. 1997) and that hybrid receptors containing a kinase-inactive receptor half will bind ligand normally but will be functionally inactive since both receptor halves must have normal kinase activity for signaling to occur (Treadway et al. 1991, Frattali \& Pessin 1993).

A dominant negative strategy to assess endogenous IGF-I receptor function has been used in a variety of cell types. Functional inactivation of endogenous IGF-I receptors with kinase-deficient IGF-I receptors has been reported in NIH-3T3 (Kato et al. 1993) and mouse wild-type fibroblasts ( $\mathrm{Li}$ et al. 1994), rat-1 fibroblasts (Prager et al. 1994, Kulik et al. 1997), rat GC pituitary cells (Prager et al. 1992, Webster et al. 1994), and rat C6 glioblastoma cells (Burgaud et al. 1995). In the present study, we find that functional inactivation of endogenous IGF-I receptors in skeletal myoblasts with a kinaseinactive, dominant negative IGF-I receptor abolishes IGF-I induced proliferation and markedly delays the onset of differentiation normally induced by serum withdrawal.

\section{Materials and Methods}

\section{Materials}

The following chemicals were purchased: ${ }^{125}$ I-IGF-I $(2000 \mathrm{Ci} / \mathrm{mmol}$ ) from Amersham Corp. (Arlington Heights, IL, USA); $\alpha-{ }^{32} \mathrm{P}-$ deoxy-CTP $(3000 \mathrm{Ci} / \mathrm{mmol})$ from DuPont-New England Nuclear (Boston, MA, USA); an anti-rat carboxy-terminal insulin receptor substrate-1 (IRS-1) antibody (rabbit polyclonal IgG, Cat. No. 06248) from Upstate Biotechnology, Inc. (Lake Placid, NY, USA); an anti-phosphotyrosine antibody coupled to horseradish peroxidase (RC20, Cat. No. E120H) from Transduction Laboratories (Lexington, KY, USA); a monoclonal antibody (G3-245) to the human retinoblastoma $(\mathrm{Rb})$ gene product (which cross-reacts with mouse $\mathrm{Rb}$ protein) from PharMingen (San Diego, CA, USA); and tissue culture medium components, fetal bovine serum (FBS) and horse serum from the Cell Culture
Facility (University of California, San Francisco, CA, USA). IGF-I was a gift from Ciba-Geigy Corp. (Summit, NJ, USA). A rat myogenin cDNA was provided by Dr WE Wright (University of Texas Southwestern Medical Center, Dallas, TX, USA).

\section{Cell culture and transfection}

C2C12 mouse skeletal muscle cells, which have been clonally purified for reproducible myogenic differentiation (Blau et al. 1983) from C2 cells (Yaffe \& Saxel 1977), were obtained from Dr H Blau (Stanford University, Palo Alto, CA, USA). Using the calcium phosphate precipitation method (Sambrook et al. 1989a), C2C12 cells were stably transfected with the constitutive $\mathrm{pECE}$ expression vector (Ellis et al. 1986) alone or expressing a full-length cDNA of a mutant, kinase-inactive human IGF-I receptor in which the ATP-binding site lysine $(\mathrm{K})$ at residue 1003 has been mutated to alanine (A) (Frattali \& Pessin 1993). Cells were cotransfected with pSV2 neo (Southern \& Berg 1982) to produce neomycin resistance. Transfected cells were then cultured in medium containing the antibiotic G418 $(400 \mu \mathrm{g} / \mathrm{ml})$. After 14-21 days, approximately 50 G418 resistant clones transfected with the insertless pECE vector or with the pECE vector containing the kinase-inactive IGF-I receptor cDNA were isolated and expanded. Of these, six randomly selected control clones and ten randomly selected clones expressing the mutant IGF-I receptor were screened for cell surface IGF-I receptor expression by binding and cross-linking studies. Subconfluent cells grown in Dulbecco's Modified Eagle's Medium (DMEM)-20\% FBS-1\% glutamine and antibiotics were studied 3 days after plating $\left(4 \times 10^{3}\right.$ cells/ $\mathrm{cm}^{2}$ ) in $16 \mathrm{~mm} 24$-well plates, $35 \mathrm{~mm}$ six-well plates, or $150 \times 25 \mathrm{~mm}$ tissue culture dishes. To induce differentiation, cells were switched into DMEM containing 2\% horse serum for up to 6 days. For IGF-I treatment studies, cells were placed in serum-free DMEM-1\% bovine serum albumin (BSA) with vehicle $(0 \cdot 1 \mathrm{M}$ acetic acid) or IGF-I for the indicated times and concentrations.

\section{Hormone binding assays}

Binding of ${ }^{125}$ I-IGF-I to cell monolayers in six-well plates was carried out as previously described (Rosenthal et al. 1991). Nonspecific binding was determined in the presence of $3 \times 10^{-8} \mathrm{M}$ unlabeled IGF-I. Binding determinations were carried out in triplicate for each concentration of unlabeled ligand. Binding in each well was normalized to total protein content (Lowry et al. 1951).

\section{Cross-linking studies}

Covalent cross-linking of ${ }^{125}$ I-IGF-I to cell monolayers was carried out with disuccinimidyl suberate as previously described (Rosenthal et al. 1994). Cells were subsequently 
solubilized and analyzed by SDS-PAGE on $5-12 \%$ gradient gels as previously described (Rosenthal et al. 1994). Samples in each lane were normalized for cellular protein. Gels were stained, destained and dried, and autoradiography was carried out.

\section{Immunoprecipitation and immunoblotting analysis}

For IRS-1 phosphorylation studies, cells were switched from DMEM-20\% FBS to DMEM-1\% BSA for $16 \mathrm{~h}$. Cells were then placed in fresh DMEM-1\% BSA in the absence or presence of IGF-I $(100 \mathrm{ng} / \mathrm{ml})$ for $1 \mathrm{~min}$ at $37^{\circ} \mathrm{C}$. Cells were rinsed twice with ice-cold PBS and lysed in ice-cold RIPA buffer (50 mM Tris- $\mathrm{HCl}, \mathrm{pH} 7 \cdot 4$; $1 \%$ nonidet P-40; $0 \cdot 25 \%$ sodium deoxycholate; $150 \mathrm{mM}$ $\mathrm{NaCl} ; 1 \mathrm{mM}$ EGTA; $1 \mathrm{mM}$ phenylmethylsulfonyl fluoride; $1 \mu \mathrm{g} / \mathrm{ml}$ each of aprotinin, leupeptin and pepstatin; $1 \mathrm{mM} \mathrm{NaVO}_{4}$; and $1 \mathrm{mM} \mathrm{NaF}$ ). Lysates normalized for total protein were pre-cleared with protein $\mathrm{A}$-agarose and treated with an anti-IRS-1 antibody for $2 \mathrm{~h}$ at $4{ }^{\circ} \mathrm{C}$. Immunocomplexes were captured with protein A-agarose beads which were subsequently washed with ice-cold RIPA buffer and placed in $2 \times$ Laemmli sample buffer. Samples were boiled for $5 \mathrm{~min}$ and analyzed by SDSPAGE on 5-12\% gradient gels. After electrotransfer and membrane blocking as previously described (Silverman et al. 1995), membranes were treated with an antiphosphotyrosine antibody coupled to horseradish peroxidase at a 1:1000 dilution in blocking buffer overnight at $4{ }^{\circ} \mathrm{C}$. Membranes were subsequently washed three times in blocking buffer, and immunoreactive bands were visualized using the enhanced chemiluminescence (ECL) detection system (Amersham ECL kit RPN 2108). Autoradiography was subsequently carried out. To measure total IRS-1 protein, blots were stripped and treated with the same anti-IRS-1 antibody used for immunoprecipitation.

For $\mathrm{Rb}$ protein phosphorylation studies, cells were lysed in sample buffer, boiled and analyzed by SDS-7.5\% PAGE as previously described (Rosenthal \& Cheng 1995). After electrotransfer, nitrocellulose blots were incubated with an anti- $\mathrm{Rb}$ protein antibody that recognizes both phosphorylated and hypophosphorylated forms of $\mathrm{Rb}$. When analyzed by SDS-7.5\% PAGE, phosphorylated forms of $\mathrm{Rb}$ migrate above an un- (or hypo-) phosphorylated form of slightly greater than $105 \mathrm{kDa}$ (Gu et al. 1993, Rosenthal \& Cheng 1995). Immunoreactive bands were visualized as previously described (Rosenthal \& Cheng 1995).

\section{$m R N A$ analysis}

Total RNA was isolated by extraction in guanidinium isothiocyanate (Sambrook et al. 1989b). RNA was quantitated by spectrophotometric determination at $260 \mathrm{nM}$. Twenty-five micrograms of RNA per sample were denatured in formaldehyde, subjected to electrophoresis in $1 \%$ agarose gels and transferred to nitrocellulose. Myogenin cDNA was labeled using random primers to a specific activity of $10^{9}$ c.p.m. $/ \mu \mathrm{g}$. Nitrocellulose membranes were pre-hybridized, hybridized and washed as described (Hartmann et al. 1990). Autoradiography was carried out, and mRNA abundance was determined by scanning densitometry.

\section{Muscle creatine kinase (MCK) assay}

At the indicated times, cells in DMEM-2\% horse serum were washed with PBS, solubilized in $50 \mathrm{mM}$ glycylglycine, $1 \%$ nonidet $\mathrm{P}-40$, and homogenized in a $1 \mathrm{ml}$ Dounce homogenizer (Olson et al. 1983). Muscle creatine kinase (MCK) assays were performed by reacting $0.1 \mathrm{ml}$ lysate with phosphocreatine and ADP-glutathione (Sigma kit procedure no. 520, Sigma Chemical Co., St Louis, MO, USA). After $30 \mathrm{~min}$, the reaction was quenched with $p$-hydroxymercuribenzoate. Color reaction was induced by the addition of $\alpha$-naphthol and $0 \cdot 05 \%$ diacetyl. Spectrophotometric readings were taken at $520 \mathrm{nM}$, and MCK units were determined from a calibration curve generated by creatine standards. MCK values were normalized to total protein content. All samples were assayed in triplicate.

\section{Cell number}

At the indicated times, cell number was determined with a hemocytometer after dissociation with $0 \cdot 25 \%$ trypsin and $0.5 \%$ EDTA at $37^{\circ} \mathrm{C}$. Determinations were carried out in triplicate for each condition. Cell viability was determined by exclusion of trypan blue (Resnicoff et al. 1995).

\section{Statistical analysis and densitometry analysis}

Cell proliferation rates, MCK and Rb data were analyzed by analysis of variance, with subsequent comparisons to control values made by unpaired $t$-test. For densitometric scanning of myogenin mRNA Northern blots and IRS-1 and $\mathrm{Rb}$ Western blots, analysis was performed on a G4 Macintosh computer using the public domain NIH Image program (developed at the US National Institutes of Health and available on the Internet at http://rsb.info.nih.gov/nih-image).

\section{Results}

\section{Cross-linking and binding studies}

Six randomly selected control clones transfected with the insertless $\mathrm{pECE}$ vector and the neomycin resistance plasmid (pSV2 neo) and ten randomly selected clones expressing both the mutant kinase-inactive IGF-I receptor and the gene for neomycin resistance were screened by IGF-I 


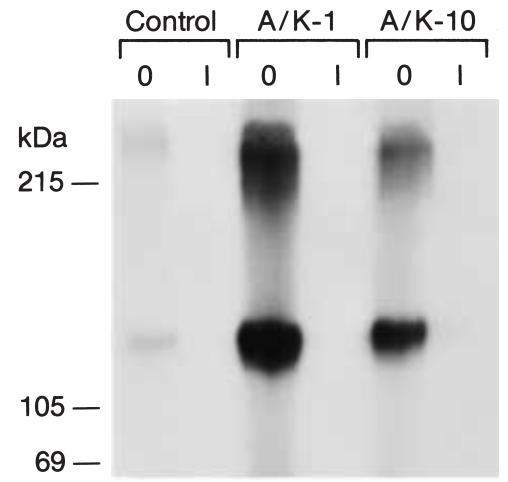

Figure 1 Cross-linking of ${ }^{125} \mathrm{I}$-IGF-I to control and A/K cells after disulfide reduction with dithiothreitol. Competition was carried out with 0 (0) or $200 \mathrm{ng} / \mathrm{ml}$ IGF-I (I). Samples in each lane were normalized for total protein and analyzed by SDS-PAGE on 5-12\% gradient gels. Molecular weight markers are indicated on the left. The band migrating at approximately $135 \mathrm{kDa}$ represents the IGF-I receptor $\alpha$-subunit. A representative of three independent experiments is shown.

binding and cross-linking studies. Hybrid receptors composed of endogenous wild-type and kinase-inactive receptor halves have been previously shown to bind ligand normally but are functionally inactive (Treadway et al. 1991, Frattali \& Pessin 1993). The two transfected clones with the highest level of mutant IGF-I receptor expression were selected for study and named $\mathrm{A} / \mathrm{K}-1$ and $\mathrm{A} / \mathrm{K}-10$. In ${ }^{125}$ I-IGF-I cross-linking studies, a $10-$ to 15 -fold increase in specific IGF-I binding was seen in $\mathrm{A} / \mathrm{K}$ versus control cells (Fig. 1). A principal band of $135 \mathrm{kDa}$, consistent with the IGF-I receptor $\alpha$-subunit, was completely abolished by unlabeled IGF-I. Of note, wild-type murine and human IGF-I receptor $\alpha$-subunits are of similar size (LeRoith et al. 1995), and similar to the human A/K IGF-I receptor which contains a point mutation in the $\beta$-subunit. A second larger band, also abolished by unlabeled IGF-I (Fig. $1)$, may represent cross-linking of two $\alpha$-subunits of the IGF-I receptor as previously described in cross-linking studies carried out under reducing conditions in myoblasts (De Vroede et al. 1984, Rosenthal et al. 1994) as well as in purified placental IGF-I receptors (Beukers et al. 1991). ${ }^{125}$ I-IGF-I competition/inhibition binding studies demonstrated a similar 13- to 15-fold increase in specific IGF-I binding in $\mathrm{A} / \mathrm{K}$ versus control cells (data not shown). No significant differences in ${ }^{125}$ I-IGF-I binding were seen among the six control clones transfected with the insertless pECE vector and pSV2 neo (data not shown).

\section{Functional inactivation of endogenous IGF-I receptors}

To determine whether overexpression of this kinaseinactive IGF-I receptor resulted in functional inactivation of endogenous IGF-I receptors in skeletal myoblasts, we examined the ability of the IGF-I receptor to phosphor-

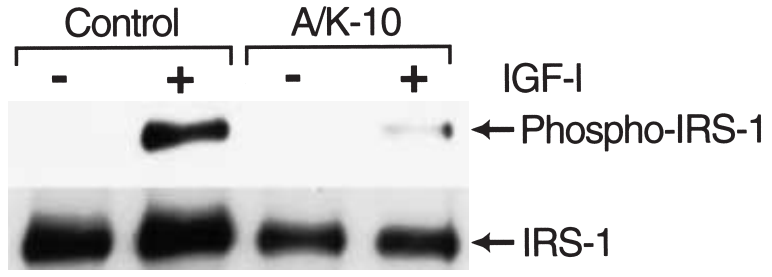

Figure 2 IRS- 1 phosphorylation in control and $\mathrm{A} / \mathrm{K}-10$ cells in the absence or presence of IGF-I ( $100 \mathrm{ng} / \mathrm{ml}$ for $1 \mathrm{~min}$ at $\left.37^{\circ} \mathrm{C}\right)$. Samples were normalized for total protein and analyzed by immunoprecipitation with an anti-IRS-1 antibody followed by Western blotting with an antiphosphotyrosine antibody. Immunoreactive bands were visualized by the ECL detection system. Blots were stripped and re-probed with an anti-IRS-1 antibody to measure total IRS-I protein, shown below. A representative of three independent experiments is shown.

ylate the principal substrate of the IGF-I receptor, IRS-1 (LeRoith et al. 1995), in response to treatment with IGF-I. A band of approximately $180 \mathrm{kDa}$ corresponding to phosphorylated IRS-1 was seen in control cells treated with IGF-I (100 ng/ml for $1 \mathrm{~min}$ ) but not in untreated control cells, as expected (Fig. 2). Phosphorylated IRS-1 was not detected in A/K-10 cells before IGF-I treatment. After IGF-I treatment, phosphorylated IRS-1 expressed as a percentage of total IRS-1 was reduced by approximately $80 \%$ in A/K-10 vs control cells (Fig. 2). Phosphorylated IRS-1 was similarly reduced in IGF-I-treated A/K-1 cells (data not shown). To confirm functional inactivation of endogenous IGF-I receptors, we examined the ability of IGF-I to induce a proliferative response in myoblasts. Cells growing in 20\% FBS-supplemented medium were switched into serum-free medium with $1 \%$ BSA in the absence or presence of $20 \mathrm{ng} / \mathrm{ml}$ IGF-I for $24 \mathrm{~h}$. This concentration of IGF-I for $24 \mathrm{~h}$ has been previously shown to stimulate a doubling in number of murine skeletal myoblasts (Ewton \& Florini 1995). IGF-I treatment resulted in a significant proliferative response in control cells; however, no proliferative effect of IGF-I was seen in either $\mathrm{A} / \mathrm{K}-1$ or $\mathrm{A} / \mathrm{K}-10$ cells (Fig. 3).

Thus, overexpression of kinase-inactive IGF-I receptors resulted in functional inactivation of endogenous IGF-I receptors as determined both by impaired IGF-I-induced IRS-1 phosphorylation in $\mathrm{A} / \mathrm{K}-1$ and $\mathrm{A} / \mathrm{K}-10$ cells and lack of a mitogenic response to IGF-I. These cells were therefore used to explore the role of the IGF-I receptor in the ability of myoblasts to begin differentiation following serum withdrawal.

\section{Functional inactivation of the IGF-I receptor delays myoblast differentiation}

To evaluate the consequences of functional inactivation of endogenous IGF-I receptors on the ability of myoblasts to undergo spontaneous differentiation following serum 


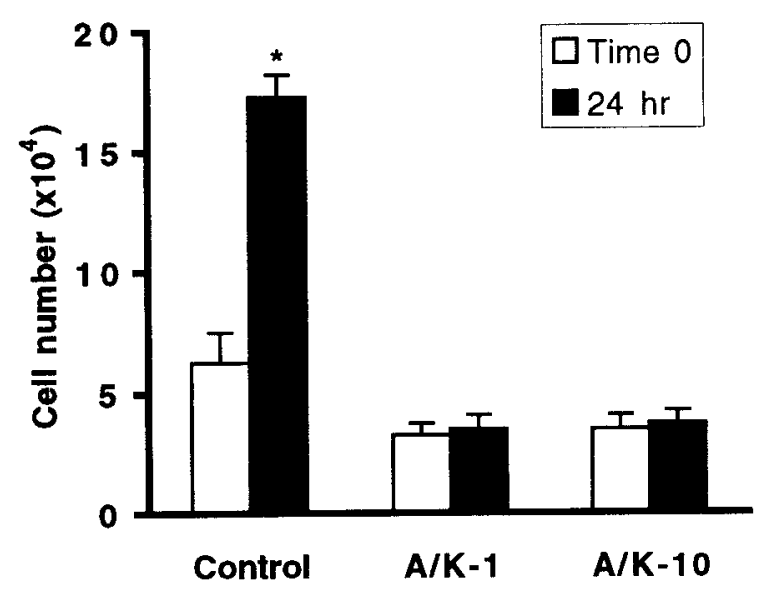

Figure 3 Cell number in control and $\mathrm{A} / \mathrm{K}$ myoblasts before and after $24 \mathrm{~h}$ treatment with IGF-I $(20 \mathrm{ng} / \mathrm{ml})$. Values shown are mean \pm S.D. of four replicates. ${ }^{*} P<0 \cdot 001$ versus time 0 for the indicated cell line. A representative of four independent experiments is shown.

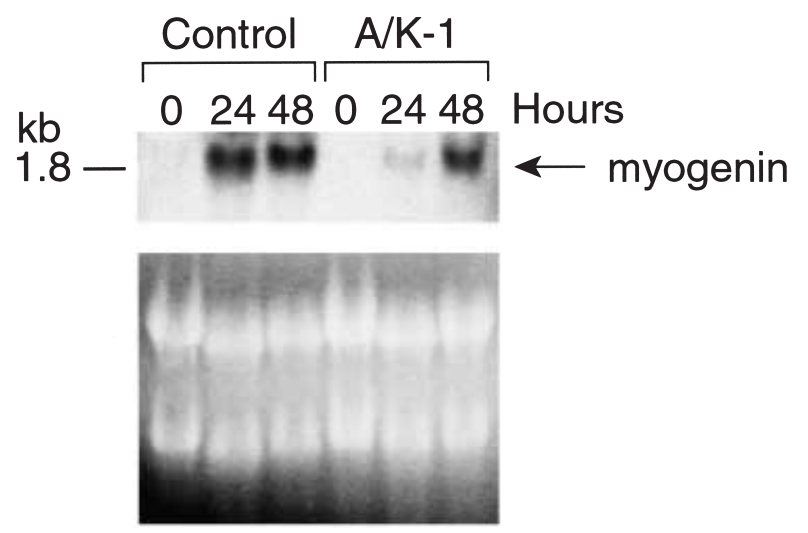

Figure 4 Northern blot of myogenin mRNA in control and A/K-1 cells for up to $48 \mathrm{~h}$ in differentiation ( $2 \%$ horse serum-supplemented) medium. Ethidium bromide staining of the gel is shown below. A representative of three independent experiments is shown.

withdrawal, myoblasts were switched from medium supplemented with $20 \%$ FBS to medium supplemented with $2 \%$ horse serum, and early and late markers of muscle cell differentiation were assessed. This reduction in serum is well known to initiate the differentiation process (Molkentin \& Olson 1996). The gene expression of myogenin, a member of the MyoD family of skeletal muscle-specific transcription factors which plays an essential role in muscle differentiation (Hasty et al. 1993, Nabeshima et al. 1993), was minimally detectable in control myoblasts in high serum and increased 10- to 20-fold after $24-48 \mathrm{~h}$ in low serum (1.8 kb mRNA) (Fig. 4), as expected. In contrast, the onset of myogenin mRNA induction was delayed in $\mathrm{A} / \mathrm{K}-1$ cells, with levels that were minimally detectable at $24 \mathrm{~h}$ and which did not increase significantly until $48 \mathrm{~h}$ in low serum (Fig. 4). A

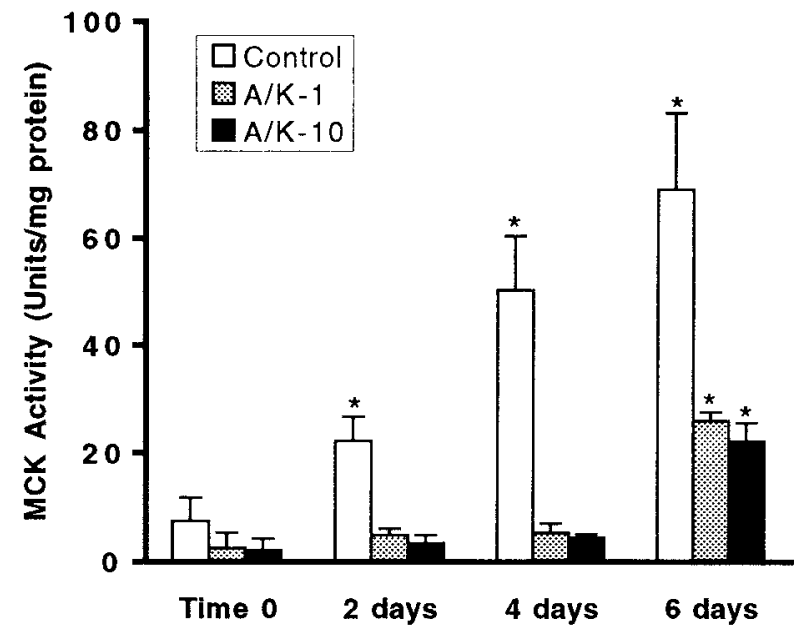

Figure 5 MCK activity in control and A/K cells for up to 6 days in differentiation medium. Values shown are the mean \pm S.D. of three independent experiments. ${ }^{*} P<0.02$ vs time 0 for the indicated cell line.

similar delay in the induction of myogenin mRNA was seen in A/K-10 cells (data not shown). In addition, expression of MCK activity, a later marker of skeletal muscle cell differentiation, was also delayed in $\mathrm{A} / \mathrm{K}$ cells. While MCK activity increased significantly over time 0 values in control cells after 2 days in low serum, a significant increase in MCK activity did not occur in $\mathrm{A} / \mathrm{K}$ cells until 6 days in low serum (Fig. 5). Of note, the percentage of viable cells was $95 \%$ in both control and $\mathrm{A} / \mathrm{K}$ cells for up to 6 days in low serum-supplemented medium (data not shown).

\section{Functional inactivation of the IGF-I receptor prolongs $R b$ phosphorylation following serum withdrawal}

To explore a potential mechanism by which functional inactivation of endogenous IGF-I receptors delays skeletal muscle cell differentiation, we examined the phosphorylation state of the ubiquitous nuclear $\mathrm{Rb}$ protein. Phosphorylated $\mathrm{Rb}$ inhibits myoblast differentiation while un- (or hypo-) phosphorylated $\mathrm{Rb}$ promotes the differentiation process (Gu et al. 1993). We therefore hypothesized that delayed differentiation in $\mathrm{A} / \mathrm{K}$ cells would be associated with prolonged $\mathrm{Rb}$ phosphorylation. When analyzed by SDS-7.5\% PAGE and immunoblotting, phosphorylated forms of $\mathrm{Rb}$ migrate above an un- (or hypo-) phosphorylated form of slightly greater than $105 \mathrm{kDa}(\mathrm{Gu}$ et al. 1993, Rosenthal \& Cheng 1995). Rb in proliferating myoblasts (maintained in serum supplemented with 20\% FBS, time 0) was present predominantly in the phosphorylated form in control as well as in A/K-1 cells (Fig. 6A). Control cells switched into medium supplemented with $2 \%$ horse serum demonstrated a progressive decrease in phosphorylated $\mathrm{Rb}$ and an increase in hypophosphorylated 
A.

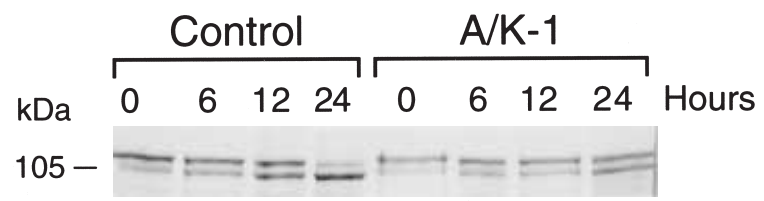

B.

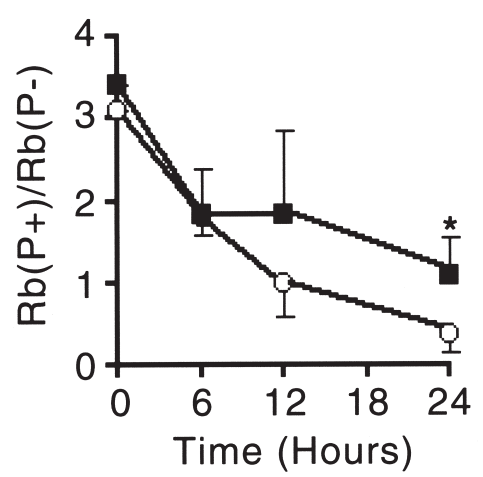

Figure 6 (A) Immunoblot of $\mathrm{Rb}$ protein phosphorylation in control and $\mathrm{A} / \mathrm{K}-1$ cells for up to $24 \mathrm{~h}$ in differentiation medium. The upper band represents the phosphorylated form of $\mathrm{Rb}$ while the lower band represents the un- (or hypo-) phosphorylated form of $\mathrm{Rb}$. A representative of three independent experiments is shown. (B) The ratio of phosphorylated $(\mathrm{P}+) \mathrm{Rb}$ to un- (or hypo-) phosphorylated (P-) Rb in control $(\bigcirc)$ and $\mathrm{A} / \mathrm{K}-1$ cells $(\mathbf{\square})$ as determined by scanning densitometry. Data represent the mean \pm S.D. of three independent experiments. ${ }^{*} P<0 \cdot 05$ for $\mathrm{A} / \mathrm{K}-1$ vs control cells at $24 \mathrm{~h}$.

$\mathrm{Rb}$, such that by $24 \mathrm{~h}$, virtually all of the $\mathrm{Rb}$ was present only in the hypophosphorylated form, typical of differentiating cells ( $\mathrm{Gu}$ et al. 1993, Rosenthal \& Cheng 1995) (Fig. 6A, B). In contrast, the $\mathrm{A} / \mathrm{K}$ mutant cells demonstrated prolonged $\mathrm{Rb}$ phosphorylation (Fig. 6A). At $24 \mathrm{~h}$, the ratio of phosphorylated to un- (or hypo-) phosphorylated $\mathrm{Rb}$ was significantly greater in $\mathrm{A} / \mathrm{K}$ vs control cells $(1 \cdot 10 \pm 0.46$ vs $0.37 \pm 0.21$ (mean \pm s.D.), $P<0.05$ ) (Fig. $6 \mathrm{~B})$. Ultimately, $\mathrm{Rb}$ was present in a predominantly hypophosphorylated form in $\mathrm{A} / \mathrm{K}$ cells, but only after $48-72 \mathrm{~h}$ in $2 \%$ horse serum-supplemented medium (data not shown).

\section{Discussion}

In the present study, we found that functional inactivation of endogenous IGF-I receptors in skeletal myoblasts with a kinase-inactive, dominant negative IGF-I receptor abolished IGF-I-induced proliferation and resulted in a delay in the differentiation process normally induced by withdrawal of exogenous growth factors. In contrast, when wild-type human IGF-I receptors were overexpressed in bovine or rodent skeletal muscle cells, an IGF-I-induced proliferative response was augmented in comparison to control cells, and differentiation occurred more rapidly than in control cells following serum withdrawal (Quinn et al. 1994, Quinn \& Haugk 1996). Previous in vivo studies demonstrated that targeted disruption of the IGF-I receptor in mice resulted in skeletal muscle hypoplasia, but those cells that were present had undergone differentiation (Liu et al. 1993). A potential limitation of the in vivo knockout study, however, is that the IGF-I receptor was absent in all tissues (Liu et al. 1993), raising the possibility that the muscle phenotype was due, at least in part, to absent IGF-I receptors in the surrounding cell types which affect skeletal muscle biology, e.g. nerve cells and endothelial cells. We therefore developed a cell autonomous model in order to examine the consequences of IGF-I receptor inactivation on the ability of skeletal myoblasts to differentiate normally.

To explore potential mechanisms by which functionally inactivated IGF-I receptors delay differentiation of skeletal myoblasts, we examined myogenin gene expression and the phosphorylation state of the cell cycle regulatory retinoblastoma protein. Myoblasts expressing a dominant negative IGF-I receptor demonstrated a marked delay in the induction of myogenin expression and MCK activity. This delay in myogenin expression likely contributes to the delay in later markers of differentiation, such as MCK activity, since myogenin is essential for skeletal muscle differentiation (Hasty et al. 1993, Nabeshima et al. 1993). In addition, we found that myoblasts expressing a dominant negative IGF-I receptor demonstrated prolonged $\mathrm{Rb}$ phosphorylation in comparison to control cells. The delayed induction of myogenin gene expression and MCK activity in cells with functionally inactive IGF-I receptors may be a consequence of prolonged $\mathrm{Rb}$ phosphorylation, since myoblast differentiation is thought to require $\mathrm{Rb}$ dephosphorylation ( $\mathrm{Gu}$ et al. 1993). In addition, the unphosphorylated but not the phosphorylated form of $\mathrm{Rb}$ can interact directly with members of the MyoD family of skeletal muscle-specific transcription factors, including myogenin ( $\mathrm{Gu}$ et al. 1993). This interaction may be required for terminal myoblast differentiation because Saos-2 osteosarcoma cells, which express a nonfunctional $\mathrm{Rb}$ protein, can be converted to skeletal muscle by cotransfection with $\mathrm{Rb}$ and myogenin expression constructs but cannot be so converted with a myogenin construct alone ( $\mathrm{Gu}$ et al. 1993). Thus, prolonged $\mathrm{Rb}$ phosphorylation itself could also contribute to delayed differentiation in $\mathrm{A} / \mathrm{K}$ myoblasts with functionally inactive IGF-I receptors.

Since IGF-I receptors can form hybrids with insulin receptors (Bailyes et al. 1997), it is possible that the delayed differentiation we observed in myoblasts expressing a dominant negative IGF-I receptor is a consequence of functional inactivation of endogenous insulin receptors as 
well as of endogenous IGF-I receptors. The contribution of insulin receptors in the present study, however, is likely to be minimal in view of studies demonstrating that insulin binding and insulin receptor mRNA are virtually nondetectable in the closely related C2 myoblasts, but increase only after myoblasts have differentiated into myocytes (Brunetti et al. 1989).

In view of recent studies which demonstrate a role for the IGF-I receptor in cell survival (Resnicoff et al. 1995, Kulik et al. 1997, Hongo et al. 1998), it is noteworthy that the percentage of viable cells was 95\% in both control and A/K myoblasts expressing the dominant negative IGF-I receptor for up to 6 days in low serum-supplemented medium. The consequences of IGF-I receptor inactivation on cell survival appear to vary with cell type and experimental conditions. In rat-1 fibroblasts, a similar IGF-I receptor $\mathrm{A} / \mathrm{K}$ mutant sensitized cells to apoptosis (Kulik et al. 1997), while expression of a closely related IGF-I receptor ATP-binding site mutant in rat C6 glioblastoma cells did not cause cell death (Burgaud et al. 1995). The lack of cell death in our studies with C2C12 myoblasts may reflect the fact that these experiments were carried out in monolayers. Numerous studies with compromised IGF-I receptors have demonstrated that decreased cell survival occurred in anchorage-independent or in in vivo conditions, yet apoptosis did not occur when the same cells were studied in monolayer (Resnicoff et al. 1995, Hongo et al. 1998).

In summary, while the IGF-I receptor is not essential for skeletal muscle differentiation, the IGF-I receptor significantly influences the timing of myoblast differentiation: overexpression of the IGF-I receptor accelerates myogenic differentiation (Quinn et al. 1994, Quinn \& Haugk 1996), while functional inactivation of the IGF-I receptor results in delayed muscle differentiation. The delayed differentiation of skeletal myoblasts with functionally inactive IGF-I receptors may result, at least in part, from prolonged phosphorylation of the $\mathrm{Rb}$ protein and delayed induction of myogenin gene expression.

\section{Acknowledgements}

This work was supported by a grant from the National Institutes of Health (R01 DK-44181) and by a Basic Research Grant (1-FY98-0129) from the March of Dimes Birth Defects Foundation to SMR, NIH grant K08 DK-02412 to SA, NIH grant DK-44093 to TAG, and an American Heart Association Postdoctoral Fellowship to EHF. We thank Carol Dahlstrom for typing the manuscript.

\section{References}

Bailyes EM, Navé BT, Soos MA, Orr SR, Hayward AC \& Siddle K 1997 Insulin receptor/IGF-I receptor hybrids are widely distributed in mammalian tissues: quantification of individual receptor species by selective immunoprecipitation and immunoblotting. Biochemical Journal 327 209-215.

Beguinot F, Kahn CR, Moses AC \& Smith RJ 1985 Distinct biologically active receptors for insulin, insulin-like growth factor I, and insulin-like growth factor II in cultured skeletal muscle cells. Journal of Biological Chemistry 260 15892-15898.

Beukers MW, Oh Y, Zhang H, Ling N \& Rosenfeld RG 1991 $\left[\mathrm{Leu}^{27}\right]$ Insulin-like growth factor II is highly selective for the type-II IGF receptor in binding, cross-linking and thymidine incorporation experiments. Endocrinology 128 1201-1203.

Blau HM, Chiu C-P \& Webster C 1983 Cytoplasmic activation of human nuclear genes in stable heterocaryons. Cell 32 1171-1180.

Burgaud J-L, Resnicoff M \& Baserga R 1995 Mutant IGF-I receptors as dominant negatives for growth and transformation. Biochemical and Biophysical Research Communications 214 475-481.

Brunetti A, Maddux BA, Wong KY \& Goldfine ID 1989 Muscle cell differentiation is associated with increased insulin receptor biosynthesis and messenger RNA levels. Journal of Clinical Investigation 83 192-198.

De Vroede MA, Romanus JA, Standaert ML, Pollet RJ, Nissley SP \& Rechler MM 1984 Interaction of insulin-like growth factors with a nonfusing mouse muscle cell line: binding, action, and receptor down-regulation. Endocrinology 114 1917-1929.

Ellis L, Clauser E, Morgan DO, Edery M, Roth RA \& Rutter WJ 1986 Replacement of insulin receptor tyrosine residues 1162 and 1163 compromises insulin-stimulated kinase activity and uptake of 2-deoxyglucose. Cell 45 721-732.

Ewton DZ \& Florini JR 1995 IGF binding proteins-4, -5 and -6 may play specialized roles during L6 myoblast proliferation and differentiation. Journal of Endocrinology 144 539-553.

Ewton DZ, Falen SL \& Florini JR 1987 The type II insulin-like growth factor (IGF) receptor has low affinity for IGF-I analogs: pleiotypic actions of IGFs on myoblasts are apparently mediated by the type I receptor. Endocrinology 120 115-123.

Florini JR, Magri KA, Ewton DZ, James PL, Grindstaff K, \& Rotwein PS 1991 'Spontaneous' differentiation of skeletal myoblasts is dependent upon autocrine secretion of insulin-like growth factor-II. Journal of Biological Chemistry 266 15917-15923.

Frattali AL \& Pessin JE 1993 Relationship between $\alpha$ subunit ligand occupancy and $\beta$ subunit autophosphorylation in insulin/insulin-like growth factor-1 hybrid receptors. Journal of Biological Chemistry 268 7393-7400.

Gu W, Schneider JW, Condorelli G, Kaushal S, Mahdavi V \& Nadal-Ginard B 1993 Interaction of myogenic factors and the retinoblastoma protein mediates muscle cell commitment and differentiation. Cell 72 309-324.

Hartmann KKP, Papa V, Brown EJ, Ullrich D, Rosenthal SM \& Goldfine ID 1990 A rapid and simple one step method for isolation of poly(A) ${ }^{+}$RNA from cells in monolayer. Endocrinology 127 2038-2040.

Hasty P, Bradley A, Morris JH, Edmondson DG, Venuti J, Olson EN \& Klein WH 1993 Muscle deficiency and neonatal death in mice with a targeted mutation in the myogenin gene. Nature 364 501-506.

Hongo A, Yumet G, Resnicoff M, Romano G, O'Connor R \& Baserga R 1998 Inhibition of tumorigenesis and induction of apoptosis in human tumor cells by the stable expression of a myristylated $\mathrm{COOH}$ terminus of the insulin-like growth factor I receptor. Cancer Research 58 2477-2484.

Kato H, Faria TN, Stannard B, Roberts CT Jr \& LeRoith D 1993 Role of tyrosine kinase activity in signal transduction by the insulin-like growth factor-I (IGF-I) receptor. Journal of Biological Chemistry 268 2655-2661.

Kulik G, Klippel A \& Weber MJ 1997 Antiapoptotic signalling by the insulin-like growth factor I receptor, phosphatidylinositol 3-kinase, and Akt. Molecular and Cellular Biology 17 1595-1606. 
LeRoith D, Werner H, Beitner-Johnson D \&Roberts CT Jr 1995 Molecular and cellular aspects of the insulin-like growth factor I receptor. Endocrine Reviews 16 143-163.

Li S, Ferber A, Miura M \& Baserga R 1994 Mitogenicity and transforming activity of the insulin-like growth factor-I receptor with mutations in the tyrosine kinase domain. Journal of Biological Chemistry 269 32558-32564.

Liu J-P, Baker J, Perkins AS, Robertson EJ \& Efstratiadis A 1993 Mice carrying null mutations of the genes encoding insulin-like growth factor I (Igf-1) and type 1 IGF receptor $(I g f 1 r)$. Cell $\mathbf{7 5}$ $59-72$.

Lowry OH, Rosebrough NJ, Farr AL \& Randall RJ 1951 Protein measurement with the Folin phenol reagent. Journal of Biological Chemistry 193 265-275.

Molkentin JD \& Olson EN 1996 Defining the regulatory networks for muscle development. Current Opinion in Genetics and Development 6 445-453.

Montarras D, Pinset C, Pérez M-C, Ilan J \& Gros F 1993 Les facteurs insulino-mimétiques: des modulateurs positifs de gè nes de régulation de la myogenèse? Comptes Rendus de l'Académie des Sciences. Serie III, Sciences de la vie 316 1025-1028.

Nabeshima Y, Hanaoka K, Hayasaka M, Esumi E, Li S, Nonaka I \& Nabeshima Y 1993 Myogenin gene disruption results in perinatal lethality because of severe muscle defect. Nature 364 532-535.

Olson EN, Caldwell KL, Gordon JI \& Glaser L 1983 Regulation of creatine phosphokinase expression during differentiation of $\mathrm{BC} 3 \mathrm{H}-1$ cells. Journal of Biological Chemistry 258 2644-2652.

Palmer RM, Thomson MG, Knott RM, Campbell GP, Thom A \& Morrison KS 1997 Insulin and insulin-like growth factor-I responsiveness and signalling mechanisms in $\mathrm{C} 2 \mathrm{C} 12$ satellite cells: effect of differentiation and fusion. Biochimica et Biophysica Acta 1355 167-176.

Prager D, Yamasaki H, Weber MM, Gebremedhin S \& Melmed S 1992 Human insulin-like growth factor I receptor function in pituitary cells is suppressed by a dominant negative mutant. Journal of Clinical Investigation 90 2117-2122.

Prager D, Li H-L, Asa S \& Melmed S 1994 Dominant negative inhibition of tumorigenesis in vivo by human insulin-like growth factor I receptor mutant. PNAS 91 2181-2185.

Quinn LS \& Haugk KL 1996 Overexpression of the type-1 insulinlike growth factor receptor increases ligand-dependent proliferation and differentiation in bovine skeletal myogenic cultures. Journal of Cell Physiology 168 34-41.

Quinn LS, Steinmetz B, Maas A, Ong L \& Kaleko M 1994 Type-1 insulin-like growth factor receptor overexpression produces dual effects on myoblast proliferation and differentiation. Journal of Cell Physiology 159 387-398.

Resnicoff M, Abraham D, Yutanawiboonchai W, Rotman HL, Kajstura J, Rubin R, Zoltick P \& Baserga R 1995 The insulin-like growth factor I receptor protects tumor cells from apoptosis in vivo. Cancer Research $552463-2469$.
Rosen KM, Wentworth BM, Rosenthal N \& Villa-Komaroff L 1993 Specific, temporally regulated expression of the insulin-like growth factor II gene during muscle cell differentiation. Endocrinology 133 474-481.

Rosenthal SM \& Cheng Z-Q 1995 Opposing early and late effects of insulin-like growth factor I on differentiation and the cell cycle regulatory retinoblastoma protein in skeletal myoblasts. PNAS 92 10307-10311.

Rosenthal SM, Brunetti A, Brown EJ, Mamula PW \& Goldfine ID 1991 Regulation of insulin-like growth factor (IGF) I receptor expression during muscle cell differentiation. Journal of Clinical Investigation 87 1212-1219.

Rosenthal SM, Hsiao D \& Silverman LA 1994 An insulin-like growth factor-II (IGF-II) analog with highly selective affinity for IGF-II receptors stimulates differentiation, but not IGF-I receptor downregulation in muscle cells. Endocrinology 135 38-44.

Sambrook J, Fritsch EF \& Maniatis T 1989a Molecular Cloning. A Laboratory Manual, edn 2, pp 3:16·30-16·40. Cold Spring Harbor: Cold Spring Harbor Laboratory Press.

Sambrook J, Fritsc EF \& Maniatis T 1989 b Molecular Cloning. A Laboratory Manual, edn 2, pp 1:7·19-7·22. Cold Spring Harbor: Cold Spring Harbor Laboratory Press.

Silverman LA, Cheng Z-Q, Hsiao D \& Rosenthal SM 1995 Skeletal muscle cell-derived insulin-like growth factor (IGF) binding proteins inhibit IGF-I-induced myogenesis in rat L6E9 cells. Endocrinology 136 720-726.

Southern PJ, \& Berg P 1982 Transformation of mammalian cells to antibiotic resistance with a bacterial gene under control of the SV40 early region promoter. Journal of Molecular and Applied Genetics $\mathbf{1}$ 327-341.

Tollefsen SE, Lajara R, McCusker RH, Clemmons DR \& Rotwein P $1989 a$ Insulin-like growth factors (IGF) in muscle development. Journal of Biological Chemistry 264 13810-13817.

Tollefsen SE, Sadow JL \&Rotwein P 19896 Coordinate expression of insulin-like growth factor II and its receptor during muscle differentiation. PNAS 86 1543-1547.

Treadway JL, Morrison BD, Soos MA, Siddle K, Olefsky J, Ullrich A, McClain DA \& Pessin JE 1991 Transdominant inhibition of tyrosine kinase activity in mutant insulin/insulin-like growth factor I hybrid receptors. PNAS $\mathbf{8 8}$ 214-218.

Webster J, Prager D \& Melmed S 1994 Insulin-like growth factor-I activation of extracellular signal-related kinase- 1 and -2 in growth hormone-secreting cells. Molecular Endocrinology 5 593-544.

Yaffe D \& Saxel O 1977 Serial passaging and differentiation of myogenic cells isolated from dystrophic mouse muscle. Nature $\mathbf{2 7 0}$ $725-727$.

Received 4 January 2000

Revised manuscript received 5 June 2000

Accepted 21 June 2000 